\title{
Can South America form an optimal monetary area? A structural vector autoregression analysis
}

\author{
León Padilla ${ }^{1}$ (D) A Ángel Rodriguez García-Brazales ${ }^{2}$ (D)
}

Accepted: 28 October 2020 / Published online: 14 November 2020

(C) The Author(s) 2020

\begin{abstract}
This research analyzes the feasibility of adopting a common currency in South America using the Optimal Monetary Areas theory. Taking into account that the relative dominance of regional shocks in local output is considered a key indicator to adopt a regional currency, we use a structural vector autoregression (SVAR) model to determine what type of shock — among global, regional or country specific — prevails in South American economies. The results of variance decomposition demonstrate that the output trajectory of South American countries is mainly explained by countryspecific shocks; therefore, South America as a whole is not considered not an optimal monetary area. However, we identified a group of countries — named Sud-5 (comprised of Chile, Peru, Ecuador, Brazil and Argentina) - for which the costs of a hypothetical monetary union would be relatively lower.
\end{abstract}

Keywords South America · Common currency · SVAR · Variance decomposition

JEL classification $\mathrm{F} 33 \cdot \mathrm{F} 36 \cdot \mathrm{F} 41 \cdot \mathrm{F} 45$

León Padilla

leon.padilla@udla.edu.ec

Extended author information available on the last page of the article 


\section{Introduction}

Recent changes in the International Monetary System (IMS) ${ }^{1}$ have led several economies to adopt regional currencies, as is the case for the euro area and the recent Monetary Area in the West African (ECOWAS) project. This scenario may have an impact on the debate about regional currencies in other economic blocs. In the case of South America (SA), the debate started with the work of Bayoumi and Eichengreen (1993), who found little support for the idea of a common currency area. Further contributions corroborate this result, with the last relevant work being that of Larrain and Tavares (2003) and the recent paper of Hafner and Kampe (2018). However, after more than twenty-five years of an unprecedented process of globalization, the case for a monetary union in SA should be revisited.

One of the main obstacles to economic integration is the reluctance of the majority of countries to forgo their sovereignty in order to achieve more regional cohesion (Dutta et al. 2020). In a global context, most researchers agree that Latin American (LA) economies maintain a low level of integration. Using a set of indicators of economic integration — suggested by the optimum currency area theory (OCA) Dorrucci et al. (2004) showed that LA was less economically integrated not only than the European Union (EU) after the adoption of the euro, but in some cases even less than the EU at the beginning of its regional integration process in the 1960s. East Asia, even with their relative lack of formal regional trade treaties, is more integrated among itself than the countries within LA (Aminian et al. 2009). Reyes et al. (2010) explained that the lower degree of integration of LA could be related to the lack of economic development of the region. Márquez-Ramos et al. (2017) proved that institutional and political factors influence economic integration in LA. These researchers showed that the terrorist attack on September 11th, 2001 and the region's policy affinity with the Revolución Bolivariana affected the economic integration process in LA. Despite this relatively low level of integration however, Basnet and Sharma (2013) determine that the economic fluctuations in the seven largest economies in LA - Argentina, Brazil, Chile, Colombia, Mexico, Peru and Venezuela - follow a similar pattern in terms of duration, intensity, response, and timing both in the long run and in the short run. Therefore, their findings suggest that these economies in LA could benefit strongly from regional cohesion and can lead the path of economic integration in the region.

In the context of LA, most relevant literature has focused on assessing the potential gains to the creation of an optimal monetary area across all LA countries or within economic blocks that maintain regional trade agreements such as MERCOSUR member countries or the Andean Community (CAN) (Eichengreen 1998; Hochreiter and Siklos 2002; Bresser-Pereira and Holland 2009; Numa 2011; Basnet and Pradhan 2017; Hafner and Kampe 2018). While Bayoumi and Eichengreen (1993) found no evidence to support the benefits to the adoption of a common currency in LA, their model has been criticized because it cannot distinguish whether the shocks are regional, global, or simply correlated local shocks (Chow and Kim 2003). Nevertheless, according to

\footnotetext{
${ }^{1}$ The establishment of the Eurozone in 1999 and the subsequent entry into circulation of the euro in 2002 led to changes in various aspects of the IMS, especially in the composition of international reserves. Subsequently, the 2008 economic crisis revealed various weaknesses of the IMS, and almost all of its features functioned incorrectly.
} 
Chow and Kim (2003) the prevalence of regional shocks may justify common monetary policy within the region independently of their nature. In other words, the relative importance of regional shocks in the trajectory of the local output is considered the key indicator of the suitability of an economy to adopt a regional currency (Zhao and Kim 2009).

Consequently, in this paper we use a regional model to identify what kind of structural shock - country-specific, regional or global shocks - prevails in SA economies. Once identified, it is possible to establish candidates who would face lower costs to integrate a currency area in SA. These results are compared with a similar analysis of eleven members of the euro area states, taking into account that eurozone is a benchmark with which to compare these kinds of monetary agreements. Additionally, contrary to previous studies that include all LA countries, our research only includes SA countries. This is because a monetary union is much more likely in this group of countries due to their geographical proximity, similar production patterns, existing trade agreements, historical aspects and a greater degree of political integration. The structure of the paper is as follows. In the second section, the OCA literature and the research related to LA are revised. The third section details the methodology and the model used. The fourth section outlines the most important findings. The fifth section assesses the costs and benefits of adopting a single currency in SA. Finally, the main conclusions of the study are presented.

\section{Literature survey}

The workhorse model of the monetary unions is still that of the optimum currency areas (OCA), developed in the seminal work by Mundell (1961), McKinnon (1963) and Kenen (1969). The theory established that the adjustment mechanisms that replace the monetary policy are factor mobility and labor market flexibility. Furthermore, the OCA theory also identified benefits and cost in order to determine the adequacy of adopting a single currency. Among the benefits, they found an increase in intra-regional trade caused by the suppression of exchange rate risk and the reduction of transaction costs; improved conditions for investment, production, and consumption; the transparency of prices; and enhanced credibility due to the adoption of an international currency and price stability. Among the costs, they identified the loss of autonomy in monetary policy, the loss of the possibility of financing fiscal deficits through monetary issuance, and the reduction of sovereignty by giving up the national currency (Obstfeld and Rogoff 1996; Visser 2004).

However, Alesina et al. (2002) argued that the higher the correlation of shocks among a new potential member of a monetary area and the member countries is, the lower the cost of losing monetary policy independence. As Frankel and Rose (1997) argue, "Countries with idiosyncratic business cycles give up a potentially important stabilizing tool if they join a currency union. Another criterion for EMU entry is therefore the cross-country correlation of business cycles. Countries with "symmetric" cycles are more likely to be members of an OCA." Consequently, if the business cycles of the members of a monetary area are synchronized, the cost of losing the monetary policy to deal with imbalances should be lower. Subsequently, Frankel (1999) determined that even when the candidate countries to join a monetary area face higher costs 
than benefits (therefore, they do not belong to an optimal monetary area), once integrated into a monetary area, the increase in both trade integration and output correlation would lead to the benefits being higher than the costs. This means that countries could meet the ex post optimality criterion, even though they did not do so ex ante.

The literature on the suitability of LA, particularly SA, to form a monetary area is limited compared to that carried out on other economic blocs. Most research has focused on certain groups of countries that maintain trade agreements, such as MERCOSUR or the Andean Community. Bayoumi and Eichengreen (1993), through the application of vector autoregression (VAR) in SA, found low correlations in supply shocks, while the correlations of the demand shocks were seven times lower than in Europe and three times lower than in Asia. In later work, Eichengreen (1998) evaluated whether a monetary union could decrease the volatility of the exchange rates of the member countries of MERCOSUR (Argentina, Brazil, Paraguay and Uruguay). Research has shown that a regional currency is not an effective option for reducing exchange rate volatility. Similarly, they also argued that a deeper integration requires the harmonization of national regulations at several levels (such as the EU). Licandro (2000) examined the degree of similarity of the supply shocks that affect the countries that make up MERCOSUR, the NAFTA and the EU. His results demonstrate that the correlations of the supply shocks of the countries of MERCOSUR have a low level of correlation compared to those of other blocs such as the EU and NAFTA. In a study conducted on countries of South and Central America, Larrain and Tavares (2003) evaluated some criteria for the creation of a monetary union while making a distinction between two types - dollarization and a regional currency - and concluded that dollarization may be an option for the countries of Central America. However, they believe that neither the dollarization nor a regional currency would be a good option for SA.

In addition to the literature related to the synchronization of supply and demand shocks, there some other works building upon the euro area experience. Hochreiter and Siklos (2002) took the criteria set out in the Maastricht Treaty as a reference for determining the level of economic convergence. His research findings showed that in the LA region, there was a low level of convergence between Brazil (the main economic referent) and the rest of the countries. Only positive convergence results were obtained with Paraguay and to a lesser extent with Chile. The authors concluded that the creation of a common currency would be costly given the low level of synchronization in economic cycles. Hochreiter et al. (2002) studied the changes in LA's monetary systems at the beginning of the twenty-first century. They argued that the LA region has a high level of heterogeneity, where countries differ in size, structure and economic policies. With respect to trade, the authors noted that although trade has significantly increased in most of the countries of the region, brought about by the regional common market agreements (such as MERCOSUR or the Andean Pact), trade integration is still deficient. In the same vein, Numa (2011) determined that both MERCOSUR and CAN require a higher level of economic and political integration to form an optimal monetary area.

Kopits (2002) carried out a comparative analysis, using the criteria set out in the Maastricht Treaty, between the countries of Central Europe (which at the time were in the process of joining the euro area) and of LA (especially those of SA). According to 
the above author, the then candidates from Central Europe appeared to be better placed to join a monetary union (euro area) than the LA countries, given the latter's less homogeneous economic structure, limited trade and low labor mobility within the LA region. Edwards (2006) analyzed empirical evidence on the economic performance of countries that form monetary unions - those that do not have their own currency - and interpreted the results with respect to LA. The analysis focused primarily on (1) sudden stops in capital flows and (2) the current account reversals. The results suggest that belonging to a monetary union has not reduced the likelihood of sudden stops in capital flow or sudden changes in the current account. In summary, the literature regarding LA countries agrees that they are not good candidates for the constitution of a monetary area.

In a more recent study, Bresser-Pereira and Holland (2009) discovered that a regional currency could improve the integration process in LA by reducing the nominal exchange rate volatility, particularly for MERCOSUR. These findings coincide with the results published by Basnet and Pradhan (2017). These authors demonstrated that MERCOSUR countries share common trends in their main macroeconomic indicators. Finally, Hafner and Kampe (2018) demonstrated that LA and its RTAs are far from being considered an optimal monetary area because these countries have marked heterogeneities in terms of income, growth and economic structure. However, the most important conclusion of his research is that the countries belonging to the CAN present better homogeneity (in terms of the openness and mobility of factors) compared to the countries belonging to MERCOSUR.

\section{Methodology}

As mentioned above, one of the most relevant aspects for the constitution of a common currency is the degree of synchronization of business cycles among the economies. The first study that analyzed the synchronization of business cycles was presented by Bayoumi and Eichengreen (1993). These authors used an autoregressive vector model to estimate both the supply and demand shocks for the various economic blocs. The researchers integrated a restriction in which the supply shocks had permanent effects on the output level, while demand shocks only had temporary effects on the output level. According to Bayoumi and Eichengreen, the presence of highly correlated or symmetrical supply shocks within a region is an indicator that a group of countries are good candidates for the constitution of a monetary union. However, an important criticism made about the approach proposed by Bayoumi and Eichengreen is that such a methodology does not allow for the distinction among different types of shocks according to their geographical origin; in other words, among country-specific, regional and global shocks.

Chow and Kim (2003) established that the prevalence of each type of shock determines the monetary system that the country should adopt (single currency, monetary union, or global agreement). In other words, if country-specific shocks prevail in an economy, the country should opt for a national currency. If regional shocks predominate in a set of economies and there is also a correlation among regional shocks, a common monetary policy or a regional exchange rate arrangement can be justified. If global shocks prevail in one region and if they similarly affect all economies 
within and outside the region, a global monetary system - or pegging to a global currency (for example, the U.S. dollar or euro) — is justified. Consequently, the strategy in this paper is to identify what kind of structural shock prevails in the countries of SA - country-specific, regional or global shocks. Once identified, it will be possible to establish candidates who could constitute a currency area.

\subsection{Model}

To identify the underlying global, regional and country-specific structural shocks, we follow a similar strategy to that of Chow and Kim (2003), Zhao and Kim (2009) and Regmi et al. (2015), and it is also based on the methodology proposed by Blanchard and Quah (1988) and King et al. (1987). In this strategy, the domestic output, $y^{d}$, faces three types of shocks: global, regional and country-specific $\left(u^{g}, u^{r}\right.$ and $\left.u^{d}\right)$ :

$$
\Delta y_{t}^{d}=\beta_{0}+\beta_{1}(L) u_{t}^{g}+\beta_{2}(L) u_{t}^{r}+\beta_{3}(L) u_{t}^{d},
$$

where $\beta_{i}(L)=\beta_{i 0}+\beta_{i 1} L+\beta_{i 2} L^{2}+\ldots$ is a polynomial function of the lag operator $(L)$. Considering Eq. (1), the model is determined by three variables: the global $\left(y^{g}\right)$, regional $\left(y^{r}\right)$ and domestic $\left(y^{d}\right)$ output. The relation of the three structural shocks to each output variable, in matrix form, is defined as follows:

$$
\left(\begin{array}{c}
\Delta y_{t}^{g} \\
\Delta y_{t}^{r} \\
\Delta y_{t}^{d}
\end{array}\right)=\left(\begin{array}{lll}
A_{11}(L) & A_{12}(L) & A_{13}(L) \\
A_{21}(L) & A_{22}(L) & A_{23}(L) \\
A_{31}(L) & A_{32}(L) & A_{33}(L)
\end{array}\right)\left(\begin{array}{c}
u_{t}^{g} \\
u_{\mathrm{t}}^{r} \\
u_{t}^{d}
\end{array}\right)
$$

where $A_{i j}(L)=a_{i j}^{0}+a_{i j}^{1} L+a_{i j}^{2} L^{2}+\ldots$, and the matrix representation is $\Delta y_{t}=A(L) u_{t}$. It is assumed that the structural shocks of each type (global, regional and countryspecific) are not correlated and that the variance is unitary-that is, $\operatorname{Var}\left(u_{t}\right)=I$. Considering that the different types of shocks are not observed, Chow and Kim (2003) propose the following restrictions to identify the innovations: (i) countryspecific shocks have no impact on the regional or global output in the long term, and (ii) regional shocks do not have an impact on the global output in the long term. ${ }^{2}$ Those restrictions are the standard ones in characterizing small open economies. Specifically, global shocks (GS) affect all economies worldwide, including at the regional and domestic levels. An example of such a global shock would be the 2008 global financial crisis. Regional shocks (RS) affect within regional and local levels. However, such shocks do not expand to other regions. An example of regional shock is the commodity price boom observed in SA between 2004 and 2014. ${ }^{3}$ Country-specific shocks (CS) only affect one particular country, and the effects of this event do not spread to other economies. Natural disasters or economic crises, such as the 2001 Argentinian economic crisis, are considered country-specific shocks. In matrix terms, the restrictions imply that certain matrix coefficients $A(L)$, which are represented in Eq. (2), are equal

\footnotetext{
${ }^{2}$ According to the authors, long-term restrictions are often subject to less criticism than short-term restrictions.

${ }^{3}$ According to the Federal Reserve economic data, the Global Price Index of All Commodities grew an average of $13 \%$ per year.
} 
to zero. That is, $A_{12}(1)=A_{13}(1)=A_{23}(1)=0$. In other words, these estimates are omitted. Consequently, through global, regional and domestic output, it is possible to identify global, regional, and country-specific shocks for a given country. ${ }^{4}$

\subsection{Data}

Our analysis included nine countries from SA (Argentina, Bolivia, Brazil, Colombia, Ecuador, Paraguay, Peru, Uruguay and Venezuela) and eleven countries from the euro area (Austria, Belgium, Finland, France, Greece, Ireland, Italy, Luxembourg, the Netherlands, Portugal and Spain), known as EMU-12..$^{5}$ The inclusion of European economies is explained by the possibility of comparing the results obtained for SA with those of an established monetary union. The panels were divided into two periods to compare different patterns over time. The first time period corresponds to annual data between 1970 and 2001. The second time period includes quarterly data, from the first quarter of 2001 to the fourth quarter of 2015 (except for Argentina, which started in the first quarter of 2004). ${ }^{6}$ Following the economic crises of the $1980 \mathrm{~s}$ and 1990s, SA countries have shown greater macroeconomic stability since the beginning of the twenty-first century, with the exception of Venezuela and Argentina. In this sense, even when SA has not carried out a monetary integration process - and therefore it is not possible to test the ex post endogeneity approach stressed by Frankel and Rose $(1997,2001)$ - the purpose of splitting the database into two periods is to verify if there were changes in the influence of regional shocks over time. For SA, the annual data were obtained from the IMF Outlook report and the quarterly reports from official sources in each country; for European countries, the source was the European Commission database.

The variable used for the SVAR model and for the identification of the different shocks is the real output of each country, in addition to the proxy variables of the regional and global real outputs. For the purpose of representing regional output, previous studies used countries with significant economic and political weights within certain regions (Chow and Kim 2003; Zhao and Kim 2009; Regmi et al. 2015). This study used the output of Chile to represent the regional output —or a "center of gravity" - from SA. This choice is justified by the fact that Chile has the best macroeconomic performance in the region (low levels of inflation, fiscal deficit, debt, and fluctuation in its nominal exchange rate). However, in the robustness check section, we use different combinations. Particularly, estimates were also calculated considering Brazil as another regional output option due to its significant representation in the total output of SA (approximately $50 \%$ of the regional output). In regard to European

\footnotetext{
${ }^{4}$ The adoption of restrictions entails the application of structural autoregressive (SVAR) models since this methodology allows for the integration of established assumptions in the economic theory, unlike traditional VAR models.

${ }^{5}$ This group of countries are known in such way because they were the first twelve members of the euro area; they also represent the most relevant countries in economic terms.

${ }^{6}$ For the quarterly data of SA, it was necessary to conduct a seasonal adjustment by the Census X-13 method, excluding Ecuador. Moreover, for the quarterly series, a qualitative variable was included as an exogenous variable, from the second quarter of 2008 until the second quarter of 2009 . This variable was included with the purpose of controlling for the effects of the 2008 economic crisis and avoiding erroneous estimates.
} 


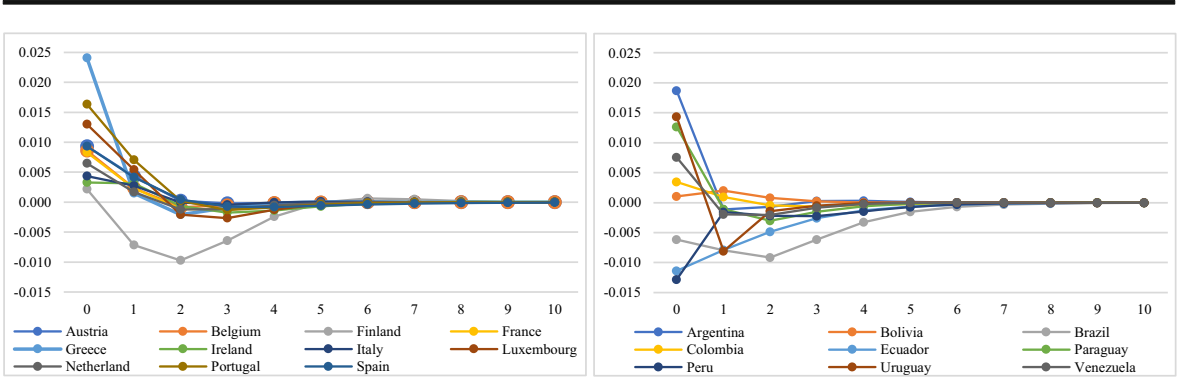

Fig. 1 Regional Shocks in Europe (left) and South America (right), 1970-2000

countries, the output of Germany was used. The real output of the United States (US) was used as the proxy variable of the global output for both blocs.

The first difference of the logarithm of the country-specific, regional and global output is included for each specification, while for an independent variable, it is the first lag of each variable, except in cases in which the adoption of another strategy is indicated. $^{7}$ The augmented Dickey-Fuller (ADF) test found that the variables do not have a unit root. Furthermore, the Johansen test revealed the absence of cointegration among the variables. All models complied with the stability conditions; in other words, their own values were within the unit circle and did not show autocorrelation in the remainder.

\section{Model results}

The results of the impulse-response function show that between 1970 and 2001, the EMU-12 countries have less sensitivity to regional shocks compared to the SA region, as shown the impulse response functions in Fig. 1. The most significant case is that of Finland, which has a much more asymmetric pattern than do the rest of the European countries. These preliminary results do not justify the creation of a monetary area in SA Subsequently, the variance decomposition was estimated for the prediction error made for a time horizon of two and ten years. This process allows us to establish the percentage of volatility that a variable experiences when faced with disturbances of other variables. ${ }^{8}$ The variance decomposition for the prediction error indicates the degree of the prediction error of the real output of each country produced by each type of shock: global, regional and country-specific. For the annual data between 1970 and 2001, predictions were made for the short (two years) and medium (ten years) term. In the euro area, regional shocks account for $24.9 \%$, on average, of real output in the short term ( 2 years) and $26 \%$ in the medium term (10 years), between 1970 and 2001 . The countries with the least impact on their output due to regional shocks were Finland, Ireland and Italy (in the short term), while Greece and Austria have the greatest

\footnotetext{
${ }^{7}$ The optimal number of lags was determined by the Akaike information criterion (AIC) and the Schwarz information criterion (SIC).

${ }^{8}$ In other words, it allows for the separation of the variance from the prediction error of each endogenous variable.
} 
Table 1 Variance decomposition of domestic output, 1970-2001

\begin{tabular}{|c|c|c|c|c|c|c|}
\hline & \multicolumn{3}{|c|}{ 2-year Horizon } & \multicolumn{3}{|l|}{ 10-year Horizon } \\
\hline & $\begin{array}{l}\text { Global } \\
\text { Shock } \\
\text { (GS) }\end{array}$ & $\begin{array}{l}\text { Regional } \\
\text { Shock } \\
\text { (RS) }\end{array}$ & $\begin{array}{l}\text { Domestic Shock } \\
\text { (DS) }\end{array}$ & $\begin{array}{l}\text { Global Shock } \\
\text { (GS) }\end{array}$ & $\begin{array}{l}\text { Regional Shock } \\
\text { (RS) }\end{array}$ & $\begin{array}{l}\text { Domestic Shock } \\
\text { (DS) }\end{array}$ \\
\hline \multicolumn{7}{|c|}{ Eurozone-12 (Core Germany) } \\
\hline Austria & 0.029 & 0.391 & 0.580 & 0.033 & 0.389 & 0.578 \\
\hline Belgium & 0.090 & 0.248 & 0.662 & 0.091 & 0.250 & 0.659 \\
\hline Finland & 0.106 & 0.088 & 0.806 & 0.109 & 0.238 & 0.653 \\
\hline France & 0.117 & 0.329 & 0.553 & 0.140 & 0.329 & 0.531 \\
\hline Greece & 0.146 & 0.535 & 0.319 & 0.145 & 0.537 & 0.318 \\
\hline Ireland & 0.152 & 0.067 & 0.781 & 0.170 & 0.095 & 0.734 \\
\hline Italy & 0.153 & 0.072 & 0.775 & 0.160 & 0.070 & 0.771 \\
\hline Luxembourg & 0.152 & 0.171 & 0.677 & 0.173 & 0.176 & 0.652 \\
\hline Netherlands & 0.165 & 0.187 & 0.648 & 0.179 & 0.194 & 0.627 \\
\hline Portugal & 0.070 & 0.343 & 0.586 & 0.090 & 0.337 & 0.573 \\
\hline Spain & 0.100 & 0.315 & 0.585 & 0.156 & 0.251 & 0.593 \\
\hline Average & 0.116 & 0.250 & 0.634 & 0.131 & 0.261 & 0.608 \\
\hline \multicolumn{7}{|c|}{ South America-10 (Core Chile) } \\
\hline Argentina & 0.023 & 0.149 & 0.828 & 0.025 & 0.149 & 0.826 \\
\hline Bolivia & 0.120 & 0.009 & 0.872 & 0.121 & 0.010 & 0.869 \\
\hline Brazil & 0.208 & 0.065 & 0.727 & 0.228 & 0.131 & 0.641 \\
\hline Colombia & 0.012 & 0.025 & 0.963 & 0.017 & 0.025 & 0.958 \\
\hline Ecuador & 0.200 & 0.173 & 0.627 & 0.194 & 0.192 & 0.614 \\
\hline Paraguay & 0.138 & 0.169 & 0.693 & 0.136 & 0.178 & 0.686 \\
\hline Peru & 0.074 & 0.052 & 0.879 & 0.086 & 0.054 & 0.901 \\
\hline Uruguay & 0.005 & 0.128 & 0.866 & 0.005 & 0.129 & 0.865 \\
\hline Venezuela & 0.079 & 0.032 & 0.889 & 0.079 & 0.035 & 0.887 \\
\hline Average & 0.095 & 0.089 & 0.816 & 0.099 & 0.100 & 0.805 \\
\hline
\end{tabular}

dominance. Nevertheless, despite showing a high incidence of regional shocks, it has also been proven that the real output variation in euro area countries mainly depends on country-specific shocks. In regard to the SA group, the regional shocks characterized by Chile's real output explain on average $8.9 \%$ in the short term and $10 \%$ in the medium term. ${ }^{9}$ The variance of the real GDP of each country is largely explained by country-specific shocks in both the short and medium term, at $81.6 \%$ and $80.5 \%$, respectively. These data suggest that between 1970 and 2000, the best option for SA countries was to maintain their domestic currencies. Two striking data are that for both Brazil and Ecuador, the shocks induced by the US explain approximately $20 \%$ (in the short and medium term) of the variance of their outputs (Tables 1 and 2).

\footnotetext{
${ }^{9}$ Due to problems of the unitary root, even after applying the first difference, it was necessary to apply the second difference for the data from Bolivia, Paraguay and Uruguay.
} 
Table 2 Variance decomposition of domestic output, 2001-2015

\begin{tabular}{|c|c|c|c|c|c|c|}
\hline & \multicolumn{3}{|c|}{ 2-quarter Horizon } & \multicolumn{3}{|c|}{ 24-quarter Horizon } \\
\hline & $\begin{array}{l}\text { Global } \\
\text { Shock } \\
\text { (GS) }\end{array}$ & $\begin{array}{l}\text { Regional } \\
\text { Shock } \\
\text { (RS) }\end{array}$ & $\begin{array}{l}\text { Domestic Shock } \\
\text { (DS) }\end{array}$ & $\begin{array}{l}\text { Global Shock } \\
\text { (GS) }\end{array}$ & $\begin{array}{l}\text { Regional Shock } \\
\text { (RS) }\end{array}$ & $\begin{array}{l}\text { Domestic Shock } \\
\text { (SD) }\end{array}$ \\
\hline \multicolumn{7}{|c|}{ Eurozone-12 (Core Germany) } \\
\hline Austria & 0.055 & 0.343 & 0.602 & 0.061 & 0.341 & 0.598 \\
\hline Belgium & 0.288 & 0.363 & 0.350 & 0.283 & 0.357 & 0.360 \\
\hline Finland & 0.173 & 0.117 & 0.710 & 0.173 & 0.117 & 0.710 \\
\hline France & 0.248 & 0.354 & 0.397 & 0.251 & 0.353 & 0.396 \\
\hline Greece & 0.162 & 0.062 & 0.776 & 0.205 & 0.136 & 0.659 \\
\hline Ireland & 0.036 & 0.005 & 0.960 & 0.036 & 0.005 & 0.960 \\
\hline Italy & 0.155 & 0.550 & 0.295 & 0.147 & 0.513 & 0.340 \\
\hline Luxembourg & 0.121 & 0.245 & 0.634 & 0.122 & 0.245 & 0.633 \\
\hline Netherlands & 0.119 & 0.296 & 0.585 & 0.136 & 0.288 & 0.576 \\
\hline Portugal & 0.056 & 0.192 & 0.752 & 0.057 & 0.191 & 0.752 \\
\hline Spain & 0.006 & 0.161 & 0.833 & 0.019 & 0.160 & 0.821 \\
\hline Average & 0.129 & 0.244 & 0.627 & 0.135 & 0.246 & 0.619 \\
\hline \multicolumn{7}{|c|}{ South America -10 (Core Chile) } \\
\hline Argentina & 0.037 & 0.113 & 0.848 & 0.037 & 0.113 & 0.848 \\
\hline Bolivia & 0.090 & 0.025 & 0.886 & 0.089 & 0.026 & 0.885 \\
\hline Brazil & 0.103 & 0.419 & 0.479 & 0.107 & 0.418 & 0.475 \\
\hline Colombia & 0.049 & 0.016 & 0.935 & 0.049 & 0.018 & 0.933 \\
\hline Ecuador & 0.080 & 0.162 & 0.758 & 0.094 & 0.174 & 0.732 \\
\hline Paraguay & 0.038 & 0.033 & 0.929 & 0.038 & 0.033 & 0.929 \\
\hline Peru & 0.013 & 0.153 & 0.833 & 0.016 & 0.157 & 0.827 \\
\hline Uruguay & 0.127 & 0.016 & 0.857 & 0.130 & 0.017 & 0.854 \\
\hline Venezuela & 0.122 & 0.018 & 0.860 & 0.122 & 0.020 & 0.858 \\
\hline Average & 0.073 & 0.106 & 0.821 & 0.076 & 0.108 & 0.816 \\
\hline
\end{tabular}

With the aim of analyzing dynamic changes from 2001 and considering several events in SA (changes in monetary systems and the reduction of internal imbalances) and Europe (adoption of a common currency and economic crisis), the methodology
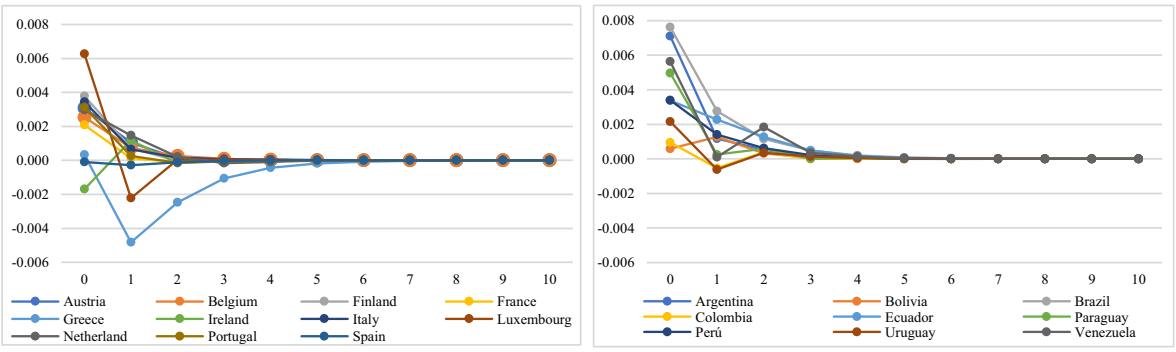

Fig. 2 Regional Shocks in Europe (left) and South America (right), 2001-2015 
was replicated using quarterly data between 2001 and $2015 .{ }^{10}$ For this dataset, predictions were made for two quarters (short term) and twenty-four quarters (medium term). Figure 2 shows that the degree of symmetry of regional shocks in the euro area declined considerably, even when controlling for the estimate with the dummy variable (crisis). The countries showing the greatest asymmetry in the regional shock trend are Luxembourg, Greece and Ireland. In contrast, SA had a greater symmetry in regional shocks compared to the previous period (1970-2001), although it could be considered deficient.

According to variance decomposition, the regional shocks in the European countries remain at similar levels to those found in the annual data, averaging $24 \%$ in the short and medium term. These results are striking; according to Frankel and Rose (1997, 2001), after forming a currency zone, the countries should increase their synchronization of business cycles. This concept is known as the ex post optimality. However, the findings show that European economies face similar levels of regional shocks, even after the entry of the euro. Ireland, which had a low level of regional shocks in the previous panel, has reduced the effect of common disturbances on the trajectory of its output. Greece has also reduced the effect of common shocks.

In contrast, Italy has significantly increased its common or regional shocks. In the case of SA, the values show that, on average, the real GDP deviations are largely explained by domestic shocks, and the regional shock levels are maintained. In general, the dominance of regional shocks in the SA economies has slightly increased compared to the period 1970-2001. However, this improvement may be considered deficient to pursue a monetary integration process throughout the region. The most relevant results are those of Ecuador (16.2\%) and Peru (15.2\%), which show a greater presence of regional shocks (represented by Chile) compared with the rest of the countries. Finally, the level of explanation of regional shocks in Brazil reaches $41.9 \%$ in both the short and medium term.

\subsection{Robustness checks}

Considering that the denomination of the regional output and the global output is arbitrary (especially in the case of the representation of the regional output by Chile, which is a relatively small economy in SA), in this section we present alternative models with different representations of both variables with the purpose of ensuring robustness in our results and we compare it with the benchmark model (BM). Table 3 reports the main results.

In the first alternative model, M1, the regional output is represented by the output of Brazil and the global output is US. We use this configuration because of the economic weight (about half of the output in SA) and international relevance. In M2 the regional output is represented by the sum of the outputs of Chile, Peru and Ecuador - countries with higher level of explanation of regional shocks in the BM and greater macroeconomic stability - and the global output by the sum of the outputs of the US and the EU.

\footnotetext{
${ }^{10}$ For this group of variables, it was necessary to make the following specifications. For the Greece model, it was necessary to include three lags since there were autocorrelation problems in the errors for the models with one and two lags. For the Spanish variable, it was necessary to make the specifications with the second difference, in addition to the logarithm, since with the first difference, there were unit root problems.
} 
Table 3 Variance decomposition in the Alternative Models

\begin{tabular}{|c|c|c|c|c|c|c|c|c|c|c|c|c|c|}
\hline & & \multicolumn{2}{|l|}{$\mathrm{BM}$} & \multicolumn{2}{|l|}{ M1 } & \multicolumn{2}{|l|}{ M2 } & \multicolumn{2}{|l|}{ M3 } & \multicolumn{2}{|l|}{ M4 } & \multicolumn{2}{|l|}{ M5 } \\
\hline & & (2) & (24) & (2) & (24) & (2) & (24) & (2) & (24) & (2) & (24) & (2) & (24) \\
\hline \multirow[t]{3}{*}{ Argentina } & GS & 0.037 & 0.037 & 0.042 & 0.044 & 0.036 & 0.037 & 0.057 & 0.083 & 0.041 & 0.054 & 0.082 & 0.090 \\
\hline & $\mathrm{RS}$ & 0.113 & 0.011 & 0.192 & 0.198 & 0.128 & 0.130 & 0.201 & 0.215 & 0.192 & 0.212 & 0.172 & 0.174 \\
\hline & DS & 0.848 & 0.848 & 0.764 & 0.757 & 0.835 & 0.833 & 0.742 & 0.702 & 0.767 & 0.734 & 0.747 & 0.736 \\
\hline \multirow[t]{3}{*}{ Bolivia } & GS & 0.090 & 0.089 & 0.068 & 0.068 & 0.055 & 0.056 & 0.088 & 0.091 & 0.068 & 0.069 & 0.112 & 0.114 \\
\hline & $\mathrm{RS}$ & 0.025 & 0.026 & 0.027 & 0.028 & 0.054 & 0.057 & 0.076 & 0.078 & 0.070 & 0.075 & .053 & 0.054 \\
\hline & DS & 0.886 & 0.885 & 0.905 & 0.903 & 0.891 & & 0.836 & & & & & 0.833 \\
\hline \multirow[t]{3}{*}{ Brazil } & GS & 0.103 & 0.107 & - & - & 0.093 & 0.097 & 0.156 & & 0.141 & 0.156 & & 0.159 \\
\hline & $\mathrm{RS}$ & 0.419 & 0.418 & - & - & 0.514 & 0.511 & 0.837 & 0.806 & 0.818 & 0.802 & 0.796 & 0.781 \\
\hline & $\mathrm{DS}$ & 0.479 & 0.475 & - & - & 0.393 & 0.393 & 0.007 & 0.007 & 0.041 & 0.042 & 0.061 & 0.060 \\
\hline \multirow[t]{3}{*}{ Chile } & GS & - & - & 0.116 & 0.120 & 0.104 & 0.105 & 0.089 & 0.100 & 0.177 & 0.178 & 0.182 & 0.187 \\
\hline & $\mathrm{RS}$ & - & - & 0.201 & 0.217 & 0.594 & 0.596 & 0.232 & 0.254 & 0.220 & 0.241 & 0.213 & 0.222 \\
\hline & DS & - & - & 0.684 & 0.663 & 0.303 & 0.298 & 0.679 & 0.647 & 0.603 & 0.581 & 0.605 & 0.591 \\
\hline \multirow[t]{3}{*}{ Colombia } & GS & 0.049 & 0.049 & 0.048 & 0.0 & 0.0 & 0.0 & 0.035 & 0.0 & 0.020 & 20 & 31 & 0.031 \\
\hline & RS & 0.016 & 0.018 & 0.055 & 0.0 & 0.0 & & 0.0 & 0. & 44 & & & 0.096 \\
\hline & DS & 0.935 & & 0.897 & & & & 0.901 & & & & & 0.873 \\
\hline \multirow[t]{3}{*}{ Ecuador } & GS & 0.08 & 0.094 & 0.081 & 0.100 & 0.070 & 0.083 & 0.284 & 0.262 & 0.271 & 0.250 & 293 & 0.271 \\
\hline & $\mathrm{RS}$ & 0.162 & 0.174 & 0.103 & 0.138 & 0.215 & 0.228 & 0.080 & & 0.063 & & 97 & 0.164 \\
\hline & DS & 0.758 & 0.732 & 0.815 & 0.762 & 0.715 & 0.689 & 0.636 & 0.581 & 0.666 & 0.603 & 10 & 0.565 \\
\hline \multirow[t]{3}{*}{ Paraguay } & GS & 0.038 & 0.038 & 0.031 & 0.031 & 0.036 & 0.036 & 0.080 & 0.081 & 0.073 & 0.073 & 0.063 & 0.063 \\
\hline & RS & 0.033 & 0.033 & 0.086 & 0.086 & 0.157 & 0.157 & 0.070 & 0.073 & 0.066 & 0.067 & 59 & 0.061 \\
\hline & DS & 0.929 & 0.929 & 0.884 & 0.883 & 0. & 08 & 0.850 & 47 & 0.8 & 61 & 78 & 0.877 \\
\hline \multirow[t]{3}{*}{ Peru } & GS & 0.013 & 0.016 & 0.018 & 0.023 & 0.013 & 0.016 & 0.284 & 0.285 & 0.318 & 0.314 & 0.273 & 0.272 \\
\hline & $\mathrm{RS}$ & 0.153 & 0.157 & 0.148 & 0.158 & 0.467 & 0.470 & 0.165 & 0.179 & 0.154 & 0.170 & 0.129 & 0.139 \\
\hline & DS & 0.833 & 0.827 & 0.834 & 0.819 & 0.520 & 0.514 & 0.551 & 0.536 & 0.527 & 0.517 & 0.599 & 0.589 \\
\hline \multirow[t]{3}{*}{ Uruguay } & GS & 0.127 & 0.13 & 0.127 & 0.133 & 0.133 & 0.135 & 0.026 & 0.042 & 0.013 & 0.021 & 0.034 & 0.042 \\
\hline & $\mathrm{RS}$ & 0.016 & 0.017 & 0.047 & 0.052 & 0.069 & 0.069 & 0.081 & 0.085 & 0.093 & 0.096 & 0.101 & 0.102 \\
\hline & DS & 0.857 & 0.854 & 0.825 & 0.816 & 0.798 & 0.796 & 0.893 & 0.873 & 0.895 & 0.882 & 0.865 & 0.855 \\
\hline \multirow[t]{3}{*}{ Venezuela } & GS & 0.122 & 0.122 & 0.120 & 0.120 & 0.114 & 0.114 & 0.089 & 0.089 & 0.109 & 0.109 & 0.070 & 0.070 \\
\hline & RS & 0.018 & 0.02 & 0.083 & 0.083 & 0.027 & 0.029 & 0.079 & 0.079 & 0.072 & 0.072 & 0.113 & 0.113 \\
\hline & DS & 0.86 & 0.858 & 0.798 & 0.798 & 0.859 & 0.857 & 0.832 & 0.832 & 0.819 & 0.819 & 0.817 & 0.817 \\
\hline \multirow[t]{3}{*}{ Average } & GS & 0.073 & 0.076 & 0.072 & 0.069 & 0.070 & 0.073 & 0.119 & 0.126 & 0.123 & 0.124 & 0.128 & 0.130 \\
\hline & RS & 0.106 & 0.097 & 0.094 & 0.102 & 0.227 & 0.229 & 0.189 & 0.199 & 0.179 & 0.193 & 0.183 & 0.191 \\
\hline & DS & 0.821 & 0.816 & 0.741 & 0.730 & 0.703 & 0.698 & 0.693 & 0.675 & 0.698 & 0.683 & 0.689 & 0.680 \\
\hline
\end{tabular}

The M3 model uses the same M2 specification for the global output, while the regional output is represented by the sum of Brazil, Colombia and Chile - the main economies of the region. In M4 and M5 for the global output we use the sum of the outputs of the US, the EU and Japan. In M4, the regional output is the sum of Brazil, Chile, Peru and Ecuador. In M5 the regional output is the sum of all SA countries (with the exception of Argentina due to data availability issues).

Although changes in the specifications of the model produce slightly different outcomes - especially when Brazil is integrated to represent the regional outputthey show consistency with those obtained in the BM. Specifically, regional shocks maintain a greater relevance in Brazil, Chile, Peru and Ecuador. Note that in the M3, 
M4 and M5 models, the dominance of regional shocks in Brazil exceeds $80 \%$ (causing the average of regional shocks for SA to increase). This is due to the strong influence of this country on regional output. Furthermore, it is important to note that Chile's output also presents a high level of explanation by the regional shocks in the different configurations. Consequently, Chile, Brazil, Peru and Ecuador would be better positioned to form a monetary area. Finally, it should be noted that in M1, M3, M4 and M5 (when Brazil integrates the regional output) demonstrates that Argentina's output is also influenced by the regional shocks. Thus, the costs of adopting a regional currency would be reduced for Argentina as long as Brazil becomes a member of the integrating group.

\section{Discussion and final considerations}

Following Mongelli (2002) and De Grauwe and Mongelli (2005), we use graphical representations to illustrate the relative position of EMU-12 and SA countries with respect to the that which reflects optimal conditions for adopting a common currency

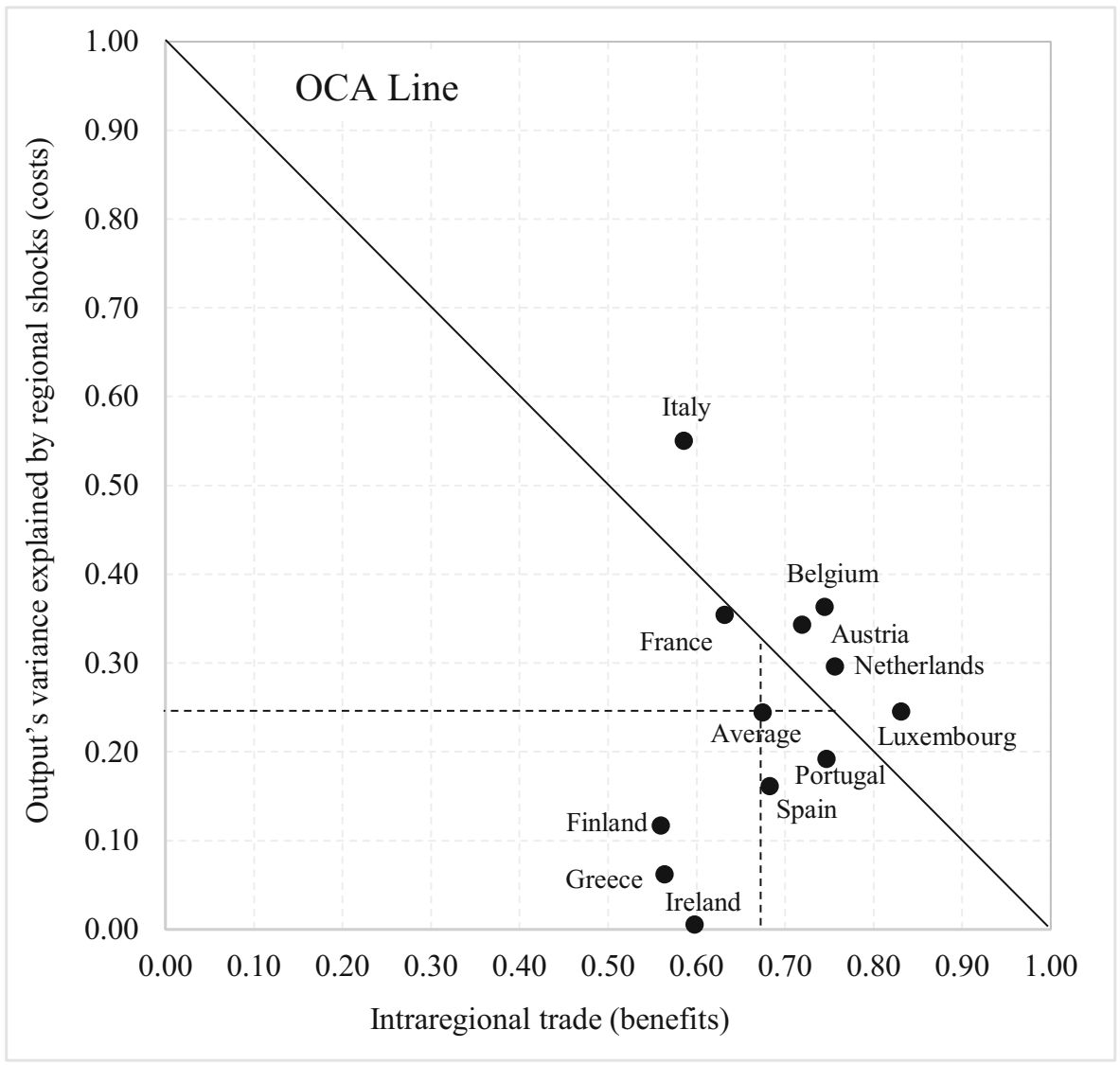

Fig. 3 Costs and benefits in EMU-12 (BM model)

Source: Trade Map. 


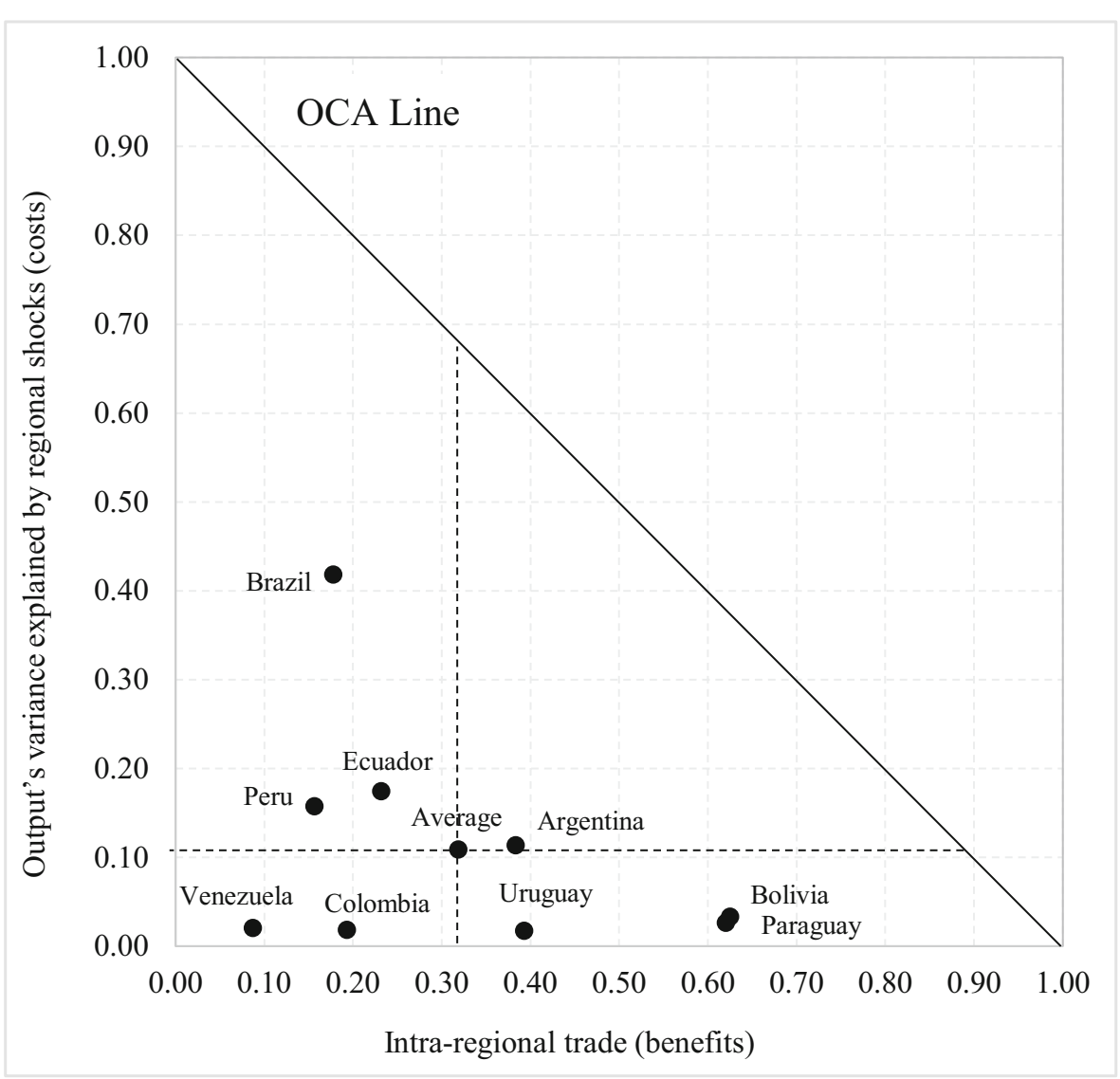

Fig. 4 Costs and benefits in South America (BM model) Source: Trade Map.

-i.e., where the benefits are greater than the costs. Taking into account that the loss of a national monetary policy instrument is more costly as the degree of business cycles asymmetry increases (Frankel and Rose 1997; Alesina et al. 2002), the costs of adopting a common currency are illustrated by variance decomposition for the prediction error of the regional shocks obtained previously. The higher the degree of explanation of the variance of the output by the regional shocks, the lower the costs of adopting a regional currency. Takin into consideration that intra-regional trade is a source of benefits of a monetary union (De Grauwe and Mongelli 2005; De Grauwe 2016), we use the intra-regional trade in the EMU-12 and SA (between 2001 and 2015) to represent the benefits. Therefore, the OCA line (downward sloping) shows the possible combinations between asymmetry (costs) and integration (benefits). Consequently, points lying to the right of the OCA line represent countries for which the benefits of a monetary union exceed its costs.

As Fig. 3 shows, the countries of the EMU-12 for which the benefits exceed the costs are Luxembourg, the Netherlands, Belgium, Austria and Italy. For SA, we use the results of the MB, M1 and M5 models to represent the possible costs. According to 


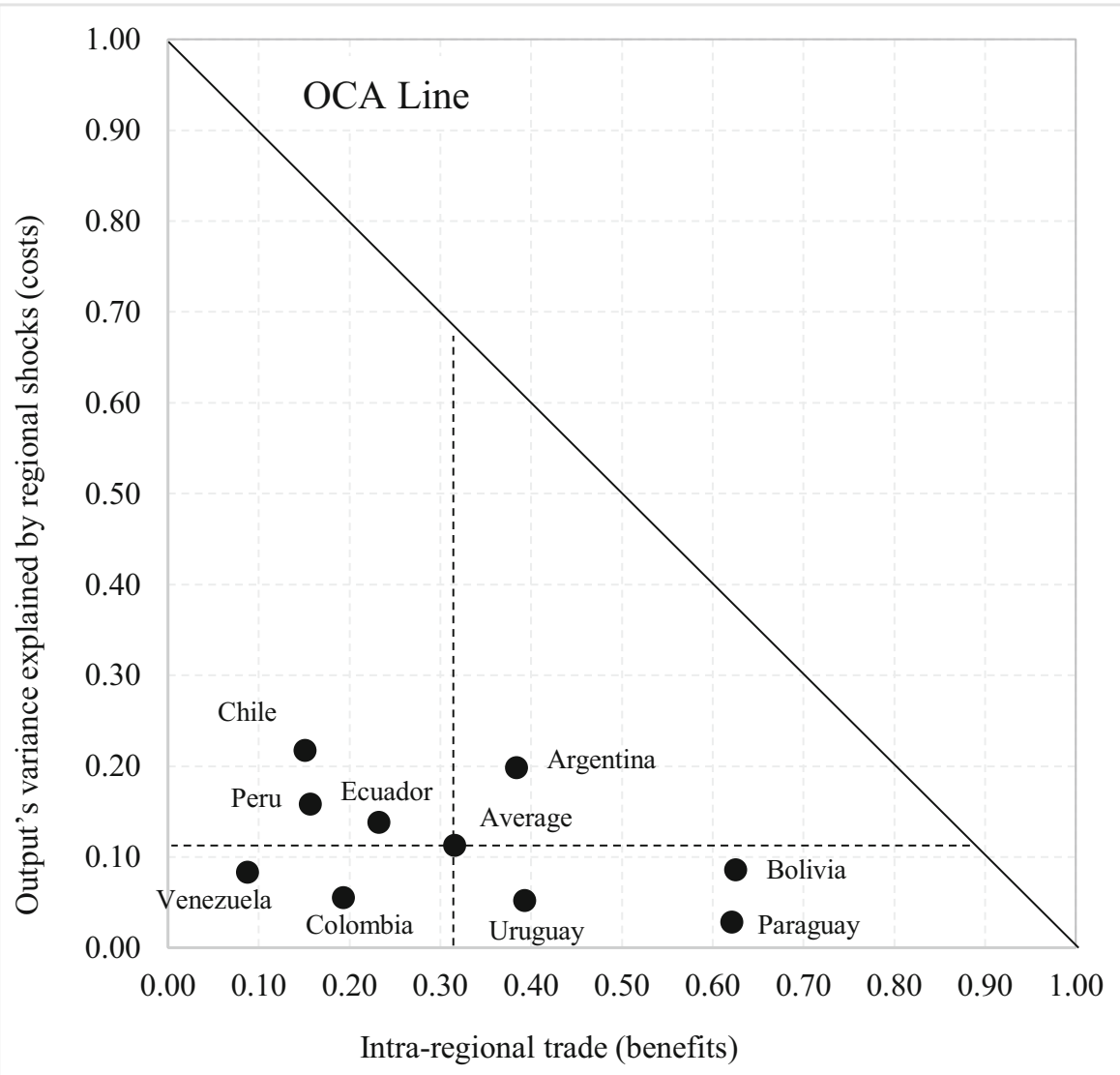

Fig. 5 Costs and benefits in South America (M1 model)

Source: Trade Map.

Figs. 4, 5 and 6, none of SA countries falls to the right of the OCA line - i.e., the costs outweigh the benefits. However, based on the results of the MB models (with Chile as core) and M1 (with Brazil as core) which are illustrated in Figs. 4 and 5, it is possible to determine that the countries with the lowest costs in a hypothetical monetary unification are: Peru, Ecuador, Chile, Brazil and Argentina. We categorize this group of countries as Sud-5. Although these economies would obtain less gains from adopting a regional currency because of their poor level of intra-regional trade, Sud-5 countries share borders that would facilitate intra-regional trade that could reduce the costs and make integration attractive. Moreover, a common currency in Sud-5 countries would allow a boost in intra-regional trade taking into account that monetary unions increase the trade between their members (Rose 2000; de Nardis and Vicarelli 2003; Bun and Klaassen 2007; Berger and Nitsch 2008). An important finding is that according to the M5 model, in which regional shocks are represented by the sum of regional output, costs increase for all countries due to, in average, the regional shocks influence is lower - only Brazil and Chile exceed the average. These outcomes raise important questions which are: what would be the best path SA countries could take to achieve monetary integration? Moreover, which country should lead this process? 


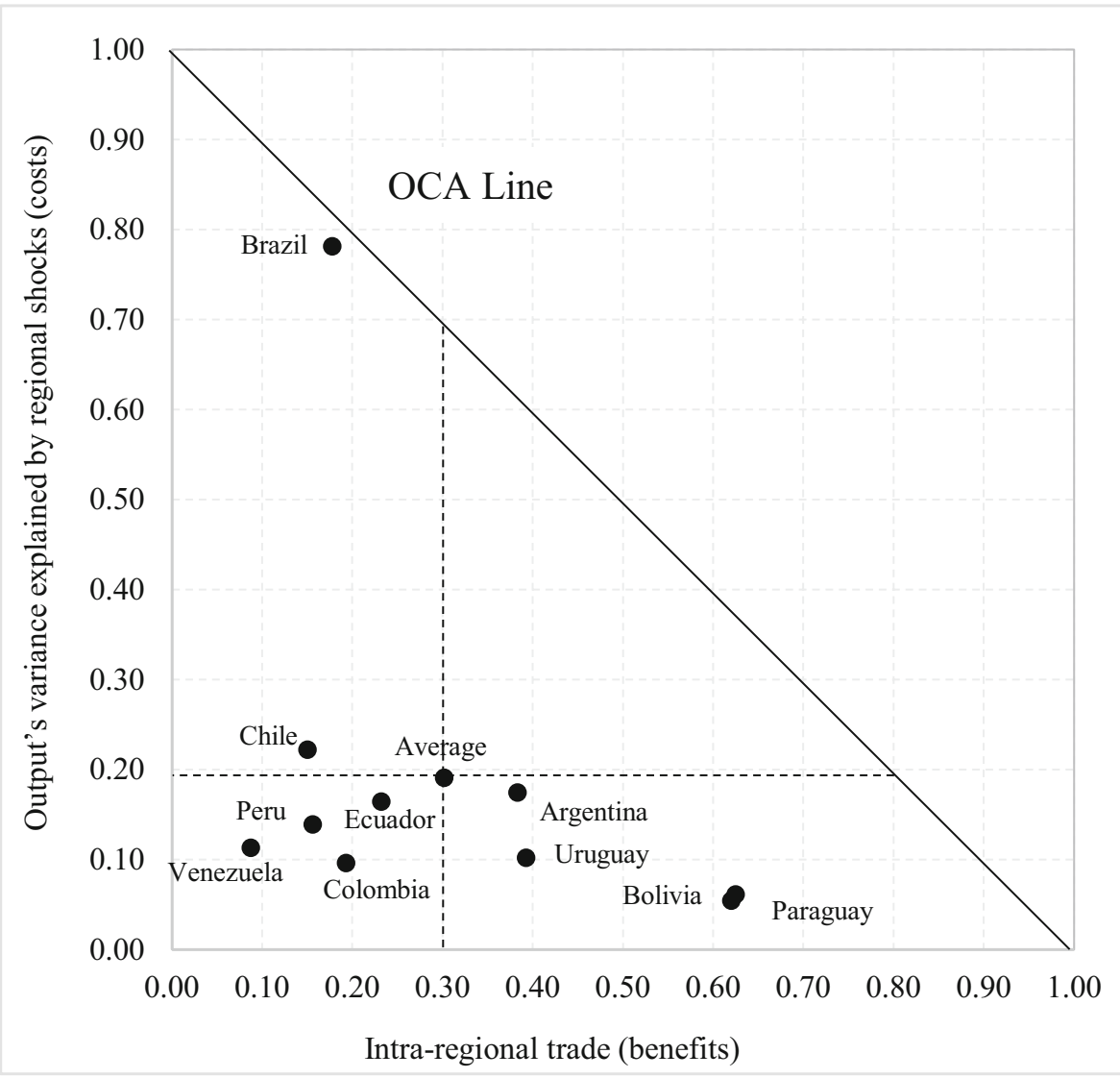

Fig. 6 Costs and benefits in South America (M5 model)

Source: Trade Map.

In relation to the first question, the most feasible path would be a partial monetary integration in which the economies that have the best conditions to adopt a common currency form a core and then other economies that meet the basic requirements can gradually integrate. Let's remember that a monetary integration in SA as a whole would increase costs for all countries. The second question is much more difficult to answer. Several authors agree that Germany played a decisive role in the creation of the euro area because this country had key characteristics to promote a monetary unification process: macroeconomic stability, institutional credibility and a solid international standing (Hadjimichalis 2011; Eichengreen 2012; Crum 2013; De Grauwe and Ji 2015). Certainly, there are two possible economies in SA that could play a central (or core) role: Brazil and Chile. On the one hand, Brazil is the region's most representative economy (approximately 50\% of SA's total GDP) and maintains a great influence on Chile's business cycle. However, the downside of this proposal is Brazil's deep macroeconomic imbalances and institutional weaknesses. Specifically, this country maintains persistent fiscal imbalances, inflationary pressures, rising unemployment rate, weaknesses in the business environment, exchange rate volatility, the highest general government gross debt in the region (87.9\% of GDP in 2018) and lack of 
"facilitating features" at the political and social level to carry out the institutional reforms that would strengthen the Brazilian economy (Coelho 2020). In addition, as several authors stress (Rivarola Puntigliano and Briceño Ruiz 2017; Scholvin and Malamud 2020), there are social, political, and structural constraints to Brazil's regional hegemony - such as location and physical barriers, the distribution of the population and economic activity, infrastructure for energy and transportation, and public policies - resulting in a disconnection of the economy from its neighbors.

On the other hand, contrary to Brazil, Chile has achieved an extended period of macroeconomic stability and solid institutional credibility. The Chilean economy is characterized by moderate levels of unemployment, price stability, better macro-fiscal performance with low levels of primary fiscal deficits and the lowest general government debt in SA (25.6\% of GDP in 2018). At the institutional level, the Chilean Central Bank demonstrates one of the highest levels of Central Bank independence globally and maintains a successful inflation-targeting framework (Venter 2020). Moreover, among the LA countries that have adopted floating regimes and inflation targets, Chile has one of the lowest rates of intervention in the exchange market (Pérez Caldentey and Vernengo 2020). In the international context, the foreign policy in Chile has also been able to consolidate long-term coherence (Minke Contreras 2020). Therefore, from a technical point of view, we think that Chile would be the most suitable core country for a possible monetary union in SA because this country better fits the basic criteria of a core player in the monetary integration process (macroeconomic stability, institutional credibility and an appropriate international reputation). However, one limitation is the low relevance of Chile in the regional economy (barely 7\% of SA's total GDP). Finally, although Chile has not risked its economic sovereignty in regional integration schemes (Fermandois 2011), in recent years Chile has shown greater regional commitment with the auspices of the Union of South American Nations (UNASUR of 2008) and the launching of regional institutions (Pacific Alliance, PA of 2012; PROSUR of 2019) (Wehner 2020).

Note: Intra-regional trade to EMU-12 is calculated as a fraction of the average exports to EMU-12 from 2001 to 2015 divided by the total average exports within the same period. The decomposition of the variance is taken from the BM model.

Note: Intra-regional trade to SA is calculated as a fraction of the average exports to SA from 2001 to 2015 divided by the total average exports within the same period. The decomposition of the variance is taken from the BM model.

Note: Intra-regional trade to $\mathrm{SA}$ is calculated as a fraction of the average exports to SA from 2001 to 2015 divided by the total average exports within the same period. The decomposition of the variance is taken from the M1 model.

Note: Intra-regional trade to SA is calculated as a fraction of the average exports to SA from 2001 to 2015 divided by the total average exports within the same period. The decomposition of the variance is taken from the M5 model.

\section{Conclusions}

The main findings in this paper are that we find EMU-12 countries' regional shocks have been similar before and after adoption of the euro (with the exception of Ireland and Greece, which have experienced a largely diminished influence of regional shocks 
in their economic fluctuations). Furthermore, the countries in which the benefits of adopting a common currency (measured as intra-regional trade) are greater than the costs (measured as the influence of regional shocks) are Italy, Belgium, Austria, the Netherlands and Luxembourg. A parallel analysis for SA countries reveals that economic disturbances are dominated by country-specific shocks and these have not changed greatly compared to the period of macroeconomic instability in the region (between 1970 and 2000). In other words, the costs of adopting a common currency would be higher for the SA economies than the EMU-12 countries. Nevertheless, although changes in the model specifications produce slightly differences outcomes - especially when Brazil is integrated to represent the regional output - the most important result of this research is the identification of a group of countries named Sud-5 (comprised of Chile, Peru, Ecuador, Brazil and Argentina), for which the costs of a hypothetical monetary union would be relatively lower. Furthermore, taking into account that monetary unions increase trade between their members, a common currency in Sud-5 would booster intra-regional trade in countries that share borders, effectively increasing the efficiency gains of forming a union. The majority of these countries belong to CAN: Peru and Ecuador are current members, and Chile, Argentina and Brazil are associate members. These results are similar to those of Hafner and Kampe (2018), who determined that CAN countries are in a better position to form a monetary area compared to MERCOSUR countries. Therefore, Sud-5 could be considered the most appropriate core for the creation of a single currency in SA, even though SA as a whole cannot be considered as an optimal monetary area.

A feasible path for SA countries would be a partial monetary integration in which the economies that have the best conditions to adopt a common currency form a core and then other economies that meet the basic requirements can gradually integrate. Certainly, the euro area showed that the creation of a monetary area can be a long and complex process (which includes trade liberalization, market integration, the creation of institutional and legal structures, and a long period of policy harmonization); however, the inclusion of new members is feasible. Nonetheless, the European experience has also shown that in order to establish a solid monetary union, it is imperative that members meet the technical criteria to avoid internal imbalances.

Finally, there are two possible economies in SA that could play a central (or core) role in monetary integration: Brazil and Chile. On the one hand, Brazil is the region's most representative economy (approximately 50\% of SA's total GDP) and maintains a great influence on Chile's business cycle. On the other hand, Chile's economy shows macroeconomic stability, institutional credibility and an appropriate international reputation. From a technical point of view, we think that Chile would be the most suitable core country for a possible monetary union in SA because this country better fits the basic criteria to be the core member of a monetary integration process. However, despite Sud-5 countries facing lower costs of adopting a common currency, it is unlikely that they will form a monetary union in the short to medium term given the low level of regional integration and the tendency to resist loss of sovereignty in SA. 
Open Access This article is licensed under a Creative Commons Attribution 4.0 International License, which permits use, sharing, adaptation, distribution and reproduction in any medium or format, as long as you give appropriate credit to the original author(s) and the source, provide a link to the Creative Commons licence, and indicate if changes were made. The images or other third party material in this article are included in the article's Creative Commons licence, unless indicated otherwise in a credit line to the material. If material is not included in the article's Creative Commons licence and your intended use is not permitted by statutory regulation or exceeds the permitted use, you will need to obtain permission directly from the copyright holder. To view a copy of this licence, visit http://creativecommons.org/licenses/by/4.0/.

\section{References}

Alesina A, Barro R, Tenreyro S (2002) Optimal currency areas. Natl Bur Econ Res Work Pap Ser No. 9072. https://doi.org/10.3386/w9072

Aminian N, Fung KC, Ng F (2009) A comparative analysis of trade and economic integration in East Asia and Latin America. Econ Chang Restruct 42:105-137. https://doi.org/10.1007/s10644-008-9059-Z

Basnet HC, Pradhan G (2017) Regional economic integration in Mercosur: the role of real and financial sectors. Rev Dev Financ 7:107-119. https://doi.org/10.1016/j.rdf.2017.05.001

Basnet HC, Sharma SC (2013) Economic integration in Latin America. J econ Integr 28:551-579. https://doi. org/10.11130/jei.2013.28.4.551

Bayoumi T, Eichengreen B (1993) One money or many? On analyzing the prospects for monetary unification in various parts of the world. Univ Calif Berkeley. Cent Int Dev Econ Res Work Pap. https://doi.org/10. 22004/ag.econ.233213

Berger H, Nitsch V (2008) Zooming out: the trade effect of the euro in historical perspective. J Int Money Financ 27:1244-1260. https://doi.org/10.1016/j.jimonfin.2008.07.005

Blanchard OJ, Quah D (1988) The dynamic effects of aggregate demand and supply disturbances. Natl Bur Econ Res Work Pap Ser No. 2737. https://doi.org/10.3386/w2737

Bresser-Pereira LC, Holland M (2009) Common currency and economic integration in Mercosul. J Post Keynes Econ 32:213-234. https://doi.org/10.2753/PKE0160-3477320206

Bun MJG, Klaassen FJGM (2007) The euro effect on trade is not as large as commonly thought. Oxf Bull Econ Stat 69:473-496. https://doi.org/10.1111/j.1468-0084.2007.00448.x

Chow HK, Kim Y (2003) A common currency peg in East Asia? Perspectives from Western Europe. J Macroecon 25:331-350. https://doi.org/10.1016/S0164-0704(03)00041-7

Coelho DR (2020) Brazil's economic reform roads. Bus Econ 55:80-91. https://doi.org/10.1057/s11369-020$00162-8$

Crum B (2013) Saving the euro at the cost of democracy? J Common Mark Stud 51:614-630. https://doi.org/ 10.1111/jcms.12019

De Grauwe P (2016) Economics of monetary union, 11th edit. Oxford University Press.

De Grauwe P, Ji Y (2015) Has the Eurozone become less fragile? Some empirical tests. J Policy Model 37 : 404 414. https://doi.org/10.1016/j.jpolmod.2015.03.003

De Grauwe P, Mongelli F (2005) Endogeneities of optimum currency areas: what brings countries sharing a single currency closer together? European Central Bank, Working Paper, No. 468.

de Nardis S, Vicarelli C (2003) Currency unions and trade: the special case of EMU. Rev World Econ 139: 625-649. https://doi.org/10.1007/BF02653107

Dorrucci E, Firpo S, Fratzscher M, Mongelli FP (2004) The link between institutional and economic integration: insights for Latin America from the European experience. Open Econ Rev 15:239-260. https://doi.org/10.1023/B:OPEN.0000037699.34047.be

Dutta T, Rawat A, Mishra A (2020) Latin America: Problems and Opportunities of Integration. pp. 241-255. https://doi.org/10.4018/978-1-7998-1730-7.ch013

Edwards S (2006) Monetary unions, external shocks and economic performance: a Latin American perspective. Int Econ Econ Policy 3:225-247. https://doi.org/10.1007/s10368-006-0056-2

Eichengreen B (1998) Does Mercosur need a single currency? Natl Bur Econ Res Work pap Ser no. 6821. https://doi.org/10.3386/w6821

Eichengreen B (2012) European monetary integration with benefit of hindsight. J Common Mark Stud 50: 123-136. https://doi.org/10.1111/j.1468-5965.2011.02231.x 
Fermandois J (2011) Pragmatism, ideology, and tradition in Chilean foreign policy since 1990 BT - Latin American foreign policies: between ideology and pragmatism. In: Gardini GL, Lambert P (eds) . Palgrave Macmillan US, New York, pp 35-52

Frankel JA (1999) No single currency regime is right for all countries or at all times. Natl Bur Econ Res Work Pap Ser No 7338. https://doi.org/10.3386/w7338

Frankel JA, Rose AK (1997) Is EMU more justifiable ex post than ex ante? Eur Econ Rev 41:753-760. https:// doi.org/10.1016/S0014-2921(97)00034-2

Frankel JA, Rose AK (2001) The Endogenity of the optimum currency area criteria. Econ J 108:1009-1025. https://doi.org/10.1111/1468-0297.00327

Hadjimichalis C (2011) Uneven geographical development and socio-spatial justice and solidarity: European regions after the 2009 financial crisis. Eur Urban Reg Stud 18:254-274. https://doi.org/10.1177/ 0969776411404873

Hafner KA, Kampe L (2018) Monetary union in Latin America: an assessment in the context of optimum currency area. Appl Econ 50:5672-5697. https://doi.org/10.1080/00036846.2018.1489116

Hochreiter E, Siklos PL (2002) Alternative exchange-rate regimes: the options for Latin America. North Am J Econ Financ 13:195-211. https://doi.org/10.1016/S1062-9408(02)00099-2

Hochreiter E, Schmidt-Hebbel K, Winckler G (2002) Monetary union: European lessons, Latin American prospects. North Am J Econ Financ 13:297-321. https://doi.org/10.1016/S1062-9408(02)00097-9

Kenen P (1969) The theory of optimum currency areas: an eclectic view. In: Mundell R, Swoboda A (eds) monetary problems of the international economy. University of Chicago Press, Chicago, pp 41-60

King R, Plosser C, Stock J, Watson M (1987) Stochastic trends and economic fluctuations. Am Econ Rev. https://doi.org/10.3386/w2229

Kopits G (2002) Central European EU accession and Latin American integration: mutual lessons in macroeconomic policy design. North Am J Econ Financ 13:253-277. https://doi.org/10.1016/S1062-9408(02) 00092-X

Larrain F, Tavares J (2003) Regional currencies versus dollarization: options for Asia and the Americas. J Policy Reform 6:35-49. https://doi.org/10.2139/ssrn.398061

Licandro G (2000) Is Mercosur an optimal currency area ? A shock correlation perspective A shock correlation perspective, Montevideo

Márquez-Ramos L, Florensa LM, Recalde ML (2017) Understanding the determinants of economic integration in Latin America. J econ Integr 32:558-585. https://doi.org/10.11130/jei.2017.32.3.558

McKinnon RI (1963) Optimum currency areas. Am Econ Rev 53:717-725

Minke Contreras J (2020) Towards development-oriented foreign policy in Latin America: the cases of Ecuador and Chile. Bull Lat Am Res. https://doi.org/10.1111/blar.13110

Mongelli F (2002) New views on the optimum currency area theory: what is EMU telling us? European Central Bank, Working Paper, No. 138.

Mundell RA (1961) A theory of optimum currency areas. Am Econ Rev Econ Rev 51:657-665

Numa M (2011) The feasibility of a monetary union in MERCOSUR. Michigan J Bus 4:11-59

Obstfeld M, Rogoff K (1996) Foundations of international macroeconomics. MIT Press, Cambridge

Pérez Caldentey E, Vernengo M (2020) The historical evolution of monetary policy in Latin America. In: Battilossi S, Cassis Y, Yago K (eds) Handbook of the history of money and currency. Springer Singapore, Singapore, pp 953-980

Regmi K, Nikolsko-Rzhevskyy A, Thornton R (2015) To be or not to be: an optimum currency area for South Asia? J Policy Model 37:930-944. https://doi.org/10.1016/j.jpolmod.2015.09.005

Reyes J, Schiavo S, Fagiolo G (2010) Using complex networks analysis to assess the evolution of international economic integration: the cases of East Asia and Latin America. J Int Trade Econ Dev 19:215-239. https://doi.org/10.1080/09638190802521278

Rivarola Puntigliano A, Briceño Ruiz J (2017) Brazil and Latin America: between the separation and integration paths. Lanham: Lexington Books.

Rose AK (2000) One money, one market: the effect of common currencies on trade. Econ Policy 15:8-45. https://doi.org/10.1111/1468-0327.00056 
Scholvin S, Malamud A (2020) Is Brazil a Geoeconomic node? Geography, public policy, and the failure of economic integration in South America. Brazilian Polit Sci Rev 14(2), e0004. https://doi.org/10.1590/ 1981-3821202000020004

Venter Z (2020) The interaction between conventional monetary policy and financial stability: Chile, Colombia, Japan, Portugal and the UK. Comp Econ Stud 62:521-554. https://doi.org/10.1057/s41294020-00129-w

Visser H (2004) A guide to international monetary Economics. Exchange rate theories, systems and policies., third edit. Edward Elgar publishing.

Wehner LE (2020) Chile's soft misplaced regional identity. Cambridge Rev Int Aff 33:555-571. https://doi. org/10.1080/09557571.2020.1752148

Zhao X, Kim Y (2009) Is the CFA franc zone an optimum currency area? World Dev 37:1877-1886. https:// doi.org/10.1016/j.worlddev.2009.03.011

Publisher's note Springer Nature remains neutral with regard to jurisdictional claims in published maps and institutional affiliations.

\section{Affiliations}

\section{León Padilla ${ }^{1}$ • Ángel Rodriguez García-Brazales ${ }^{2}$}

Ángel Rodriguez García-Brazales

angel.rodriguez@uam.es

1 Economics and Business Research Center (CIEE), Faculty of Economics \& Business, Universidad de las Américas, St. de los Granados E12-41y Colimes, EC170125 Quito, Ecuador

2 Department of Economic Analysis: Economic Theory and Economic History, Faculty of Economics \& Business, Universidad Autonoma de Madrid, Ciudad Universitaria de Cantoblanco, 28049 Madrid, Spain 